\title{
日本近海における津波発生とテクトニクス
}

\author{
東京管区気象台 渡 辺偉 夫 \\ (昭和 60 年 11 月 18 日受理)
}

\section{Tsunami Occurrence and Tectonics off the Coast of Japan}

\author{
Hideo Watanabe \\ Tokyo District Meteological Observatory
}

(Received November 18, 1985)

The shape of tsunami source deforms ususlly elliptic and the earthquake origin situates on the edge of the tsunami elliptic source. Then, it seems that the tsunami occurrence elongates apparently from one edge of tsunami source to another.

The subject of this report is to study the relationship between such apparently elongated tsunami source and tectonics near occurrence area. Some obtained results are followings.

1) The apparently elongated direction of tsunami source has a close relation with the sea depth of tsunami occurrence area, plate formation and earthquake mechanism.

2) Tsunami sources is parallel to iso-depth lines, however, vertical to them in the Tokachi-oki and the Hyuganada, corresponding to changed point of the Pacific and the Philippine plates.

3) The elongated direction of tsunami source is parallel to the slip direction of earthquake fault in the Tokachi-oki, the Boso-oki and the Hyuganada, and vertical to other areas. This depends with the slip angle of earthquake fault.

4) Tsunami amplitude and earthquake intensity seem to be large at the direction of earthquake fault.

In general, it seems that tsunami occurrence and tectonics at the changed points, are more complicated than other ones.

\section{§1. まえがき}

津波の波源の形は一般にだ円であるが，津波規模が大きくなればなる注ど，長だ円となる傾 向にある、ところが，地震の震源地（地表では震央），つまり地震が最初に引き金を引くと考 えられている点は，このだ円の一端であることが多い。この時，津波の波源形成は見かけ上だ 円の一端から他の一端へ延びた形をとる.

このよらな波源形成に関する見かけ上の延びは，津波を発生した地震断層の走向あるいはす ベりの方向，過去の活断層，海底地形などの津波発生海域のテクトニクスとどのような関係に あり，さらに，津波の振幅の大小が波源形状とどのよらな関係にあるかを調べてみたのが，本 調査研究である。このよらな研究はあまりなされていないのではないかと思ら。 
Table 1. List of Tsunamis used in this study

\begin{tabular}{|c|c|c|c|c|c|c|c|c|c|c|c|c|c|c|c|c|}
\hline \multirow{2}{*}{ No. } & \multicolumn{5}{|c|}{ origin Time } & \multicolumn{4}{|c|}{ Origin } & \multirow[b]{2}{*}{$\begin{array}{r}\text { Depth } \\
\mathrm{km}\end{array}$} & \multicolumn{3}{|c|}{ Magnitude } & \multirow{2}{*}{$\mathrm{m}_{\mathrm{H}}$} & \multirow{2}{*}{$\begin{array}{l}\text { Apparent } \\
\text { Direction } \\
\text { o }\end{array}$} & \multirow[t]{2}{*}{ Reference } \\
\hline & $\mathrm{Y}$ & $\mathbf{M}$ & D & H & M & Lat & ${ }^{*} \mathrm{~N}$ & Long & & & $M$ & $\mathrm{M}_{t}$ & $\mathrm{~m}$ & & & \\
\hline 1 & 1933 & 3 & 3 & 2 & 31 & 39 & 14 & 144 & 31 & 10 & 8.1 & 8.3 & 3 & 3 & $\mathrm{~N} 183 \mathrm{E}$ & Sanriku Tsunami \\
\hline 2 & 1938 & 5 & 23 & 16 & 18 & 36 & 39 & 141 & 35 & 0 & 7.0 & 7.5 & -1 & 0.5 & N193E & Fukushimaken-oki Tsunami \\
\hline 3 & 1938 & 11 & 5 & 17 & 43 & 37 & 20 & 142 & 11 & 30 & 7.5 & 7.6 & 0 & 1 & $\mathrm{~N} 214 \mathrm{E}$ & $n$ \\
\hline 4 & 1938 & 11 & 5 & 19 & 50 & 37 & 17 & 141 & 39 & 30 & 7.3 & 7.6 & 0 & & $\mathrm{~N} 214 \mathrm{E}$ & $n$ \\
\hline 5 & 1938 & 11 & 7 & 6 & 39 & 36 & 58 & 141 & 33 & 20 & 6.9 & 7.4 & 0 & & NI99E & $"$ \\
\hline 6 & 1940 & 8 & 2 & 0 & 8 & 44 & 15 & 139 & 28 & 10 & 7.5 & 7.7 & 2 & 1.5 & N168E & Kamuimisaki Tsunami \\
\hline 7 & 1944 & 12 & 7 & 13 & 35 & 33 & 48 & 136 & 37 & 30 & 7.9 & 8.1 & 3 & 2.1 & $\mathrm{~N} 45 \mathrm{E}$ & Tonankai Tsunami \\
\hline 8 & 1946 & 12 & 21 & 4 & 19 & 33 & 02 & 135 & 37 & 20 & 8.0 & 8.1 & 3 & 2.5 & $\mathrm{~N} 107 \mathrm{~W}$ & Nankai Tsunami \\
\hline 9 & 1947 & 11 & 4 & 9 & 9 & 43 & 49 & 141 & 01 & 0 & 6.7 & & 1 & 1 & $\mathrm{~N} 69 \mathrm{~W}$ & \\
\hline 10 & 1952 & 3 & 4 & 10 & 23 & 41 & 48 & 144 & 08 & 0 & 8.2 & 8.2 & 2 & 2.5 & $\mathrm{~N} 40 \mathrm{E}$ & Tokachi-oki Tsunami \\
\hline 11 & 1953 & 11 & 26 & 2 & 49 & 33 & 59 & 141 & 43 & 60 & 7.3 & 7.8 & 1 & 1.5 & $\mathrm{~N} \quad 47 \mathrm{E}$ & Boso-oki Tsunami \\
\hline 12 & 1960 & 3 & 21 & 2 & 7 & 39 & 50 & 143 & 26 & 0 & 7.2 & 7.5 & 0 & 0.5 & $\mathrm{~N} 154 \mathrm{E}$ & \\
\hline 13 & 1961 & 2 & 27 & 3 & 10 & 31 & 36 & 131 & 51 & 40 & 7.0 & 7.5 & 0 & 0 & $\mathrm{~N} \quad 4 \mathrm{E}$ & \\
\hline 14 & 1964 & 6 & 16 & 13 & 1 & 38 & 21 & 139 & 11 & 40 & 7.5 & 7.9 & 2 & 2 & $\mathrm{~N} 18 \mathrm{E}$ & Nigata Tsunami \\
\hline 15 & 1968 & 4 & 1 & 9 & 42 & 32 & 17 & 132 & 32 & 30 & 7.5 & 7.7 & 1 & 1 & N $70 \mathrm{~W}$ & Hyuganada Tsunami \\
\hline 16 & 1968 & 5 & 16 & 9 & 49 & 40 & 44 & 143 & 35 & 0 & 7.9 & 8.2 & 2 & 2.5 & N $34 \mathrm{~W}$ & Tokachi-oki Tsunami \\
\hline 17 & 1970 & 7 & 26 & 7 & 41 & 32 & 04 & 132 & 02 & 10 & 6.7 & 7.1 & -1 & & $\mathrm{~N} 84 \mathrm{~W}$ & \\
\hline 18 & 1972 & 2 & 29 & 18 & 23 & 33 & 11 & 141 & 16 & 70 & 7.1 & 7.6 & -1 & 0.5 & $\mathrm{~N} 18 \mathrm{~W}$ & \\
\hline 19 & 1978 & 6 & 12 & 17 & 14 & 38 & 09 & 142 & 10 & 40 & 7.4 & 7.4 & -1 & 0.5 & $\mathrm{~N} 13 \mathrm{E}$ & Miyagiken-oki Tsunami \\
\hline 20 & 1982 & 7 & 23 & 23 & 24 & 36 & 11 & 141 & 57 & 30 & 7.0 & & -1 & 0 & $\mathrm{~N} 92 \mathrm{~W}$ & \\
\hline 21 & 1983 & 5 & 26 & 11 & 59 & 40 & 21 & 139 & 05 & 14 & 7.7 & 8.1 & 3 & 2.5 & $\mathrm{~N} 10 \mathrm{E}$ & Nihonkai-chubu Tsunami \\
\hline 22 & 1983 & 6 & 21 & 15 & 25 & 41 & 15 & 139 & 00 & 6 & 7.1 & & 0 & 0.5 & $\mathrm{~N} 90 \mathrm{E}$ & \\
\hline 23 & 1969 & 8 & 12 & 6 & 28 & 42 & 42 & 147 & 37 & 30 & 7.8 & 8.2 & 1 & 2 & $\mathrm{~N} 67 \mathrm{E}$ & \\
\hline 24 & 1971 & 9 & 6 & 3 & 35 & 46 & 40 & 141 & 23 & 0 & 6.9 & & 0 & 0.5 & $\mathrm{~N} 37 \mathrm{E}$ & \\
\hline 25 & 1973 & 6 & 17 & 12 & 55 & 42 & 58 & 145 & 57 & 40 & 7.4 & 8.1 & 1 & 1.5 & $\mathrm{~N} 56 \mathrm{E}$ & \\
\hline
\end{tabular}

\section{§2. 使用した津波}

1982 年末での津波については筆者 (1983) の表から，その後の津波については調查報告 [た と壳ば気象庁 (1984)]などから，1926 年以降の津波で，波源が決められており，さらに，震 央が波源の長軸の中心からずれているものを用いた。これが Table 1 である.

この Table と拈いて, 震源は気象庁決定の値, マグニチュード闌の $M$ は気象庁決定の地 震マグニチュード， $M_{t}$ は阿部の津波マグニチュード， $m$ は今村・飯田の， $m_{H}$ は羽島の津波 規模階級で，これらの值は上記筆者の表の汪か，羽鳥 (1983a，1983b，1984）之気象庁 (1984) から取つた．津波の波源と検潮記録による初動と最大波高は羽鳥 (1978, 1981，1883a，1983b， 1984)，渡辺（1964）打よび気象庁（1965，1984）を参考にした．Table にある波源の方向と は，波源の一端からだ円の長軸汇沿つて，見かけ上延びたと思われる方向（以下波源の延びの 方向と略称) である.

地震のメカニズムは ICHIKAWA $(1971,1980)$, 気象庁 (1984) 㧍よび東大地震研究所 (1973) から採用した。震度は気象庁 $(1983,1984)$ と太田との他 (1983), さらに活断層については活 断層研究会 (1980) の資料を用いた。

\section{§3. 波源の延びの方向}

Fig. 1 は波源の延びの方向を示したものである.ただし，サハリンの津波 (Table 1 の 


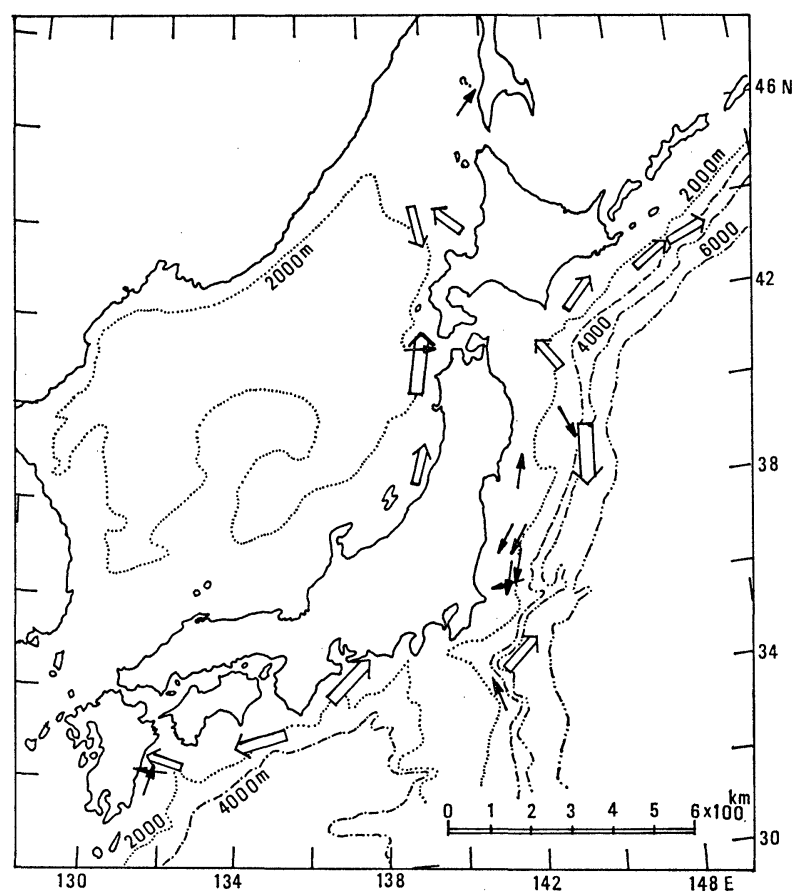

Fig. 1. Apparently elongated directions of tsunami source shown in allow heads. The heads are classified by grade magnitude of tsunami $(m)$, the largest one: $m=3$ or 4 , the middle one: $m=1$ or 2 and the smallest one: $m=-1$ or 0 .

No. 24) は気象庁，アメリカ (CGS) およびソ連においてそれぞれ決定した震源が若干異なり， アメリカとソ連の震央は波源の南端付近で, 気象庁のものは漂ぼ中央となつている.そこで, アメリカの震央を用いた場合の方向を示したもので, 他の津波で用いた気象庁の震央でないと いら意味で，疑問符を付してある．矢印の大きさは，最も大きいものは $m=3$ か 4 ，中くらい のものは $m=1$ か 2 , 小さいものは $m=-1$ か 0 の津波である.

これを見ると，データ数が必ずしも多いとはい充ないが，いくつかの特徵が見られる.

太平洋側の津波について，十勝沖以北では北向き，三陸沖から茨城県沖をで南向き，房総沖 では再び北向きの延びとなつている．東南海津波と南海津波とでは方向が逆となり，日向灘で は 2 つが西向き，1つが北向きの延びである. 日本海のものについて，一般に北向きの延びで あるが，1940 年の神威胛津波だけが南向さの延びである．これらのことは，津波発生海域の プレートの形状が主として関係していると考兄らる。.すなわち, 太平洋側では, 十勝沖と房 総沖の海溝軸の折れ曲りの位置で方向が異つていることは，プレートのもぐり达みの形状との 関係を暗示しているょうである。をた，日本海側では，神威岬津波だけが反対となつているこ とは，最近話題となつている南北の日本海東縁の境界の存在 [中村 (1983)] が関係していない であろらか。 


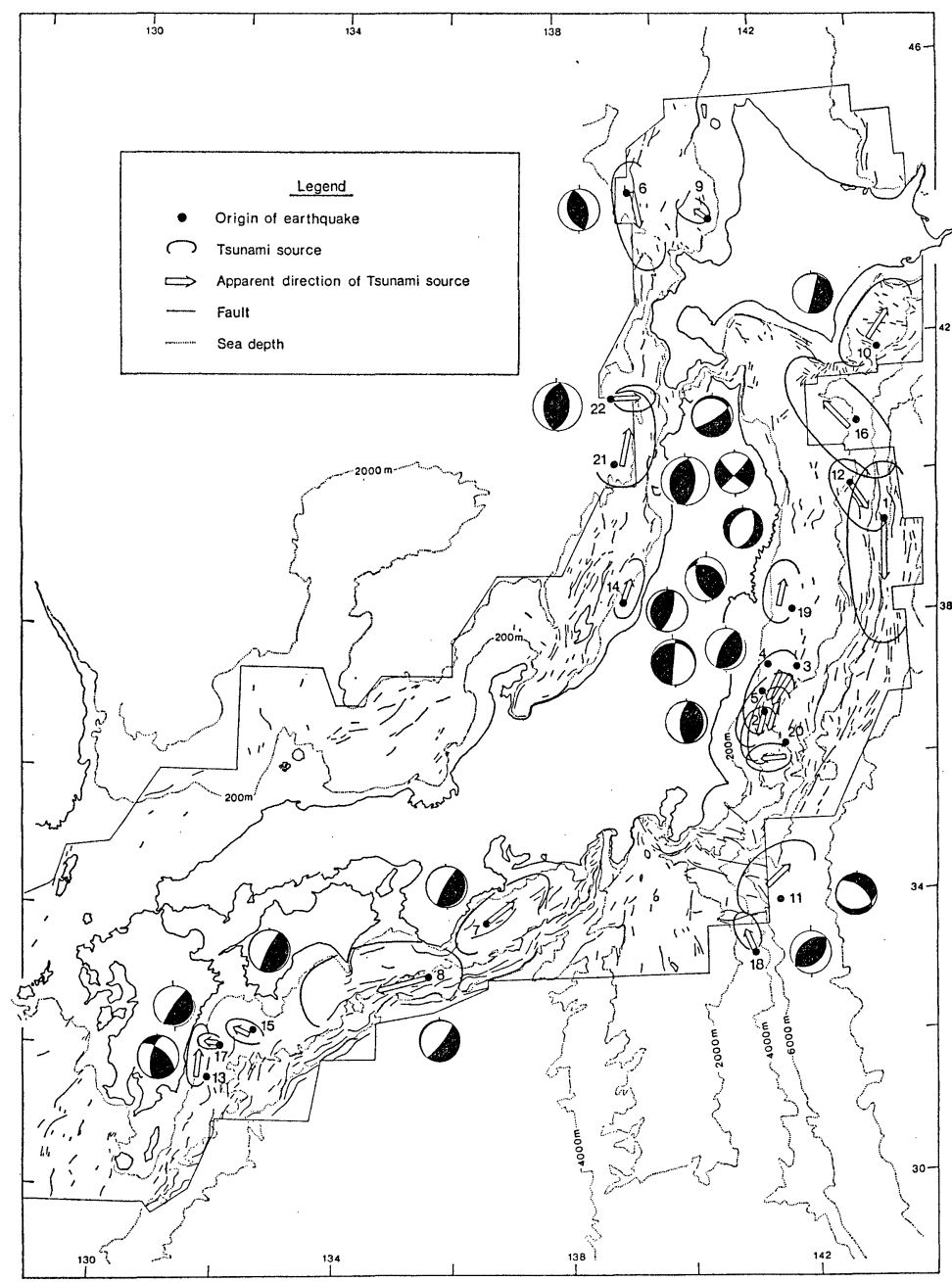

Fig. 2. Earthquake origins, its mechanisms, tsunami sources, its apparently elongated directions, active faults and sea depth off the coast of Japan.

\section{§4. 地震のメカニズム, 活断層および海深との関係}

Fig. 2 には, 津波の波源, その延びの方向, 地震のメカニズム, 海域の活断層㐨よび海深が 示されている.

これから，次の特徵が見られる。

1) 波源の延びの方向は，一般に等深線の方向に沿つている．ただし，十勝沖と日向灘に直 角に近いものがある、これは海溝軸の折れ曲りの位置と関係がありそうである.

2) 延びの方向が地震のメカニズムから推定される断層のずへのの方と泳汸一致している ところは, 十勝沖と房総沖および日向灘のいくつかである. その他の大部分は断層の走向とほ ぼ一致している. 
(a)
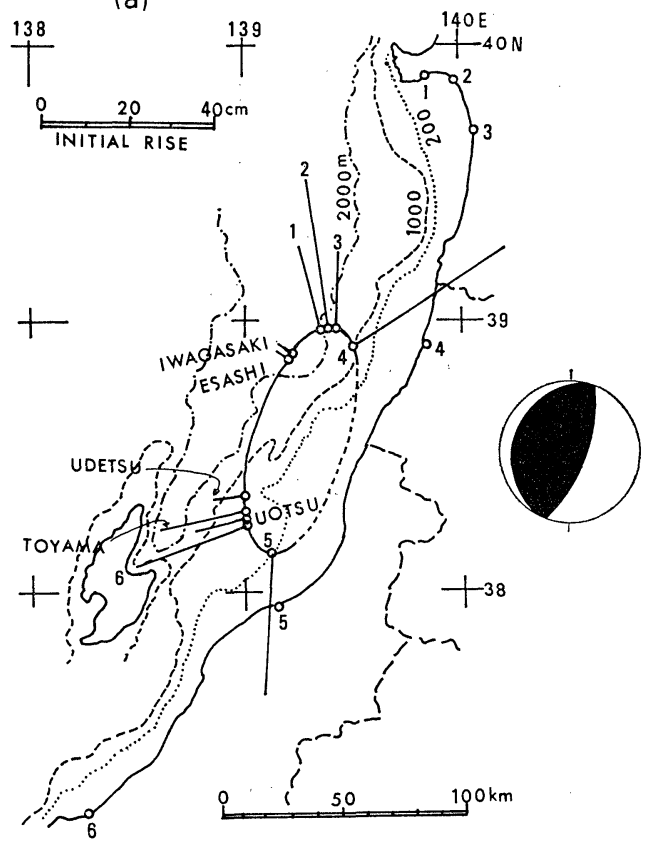

(b)

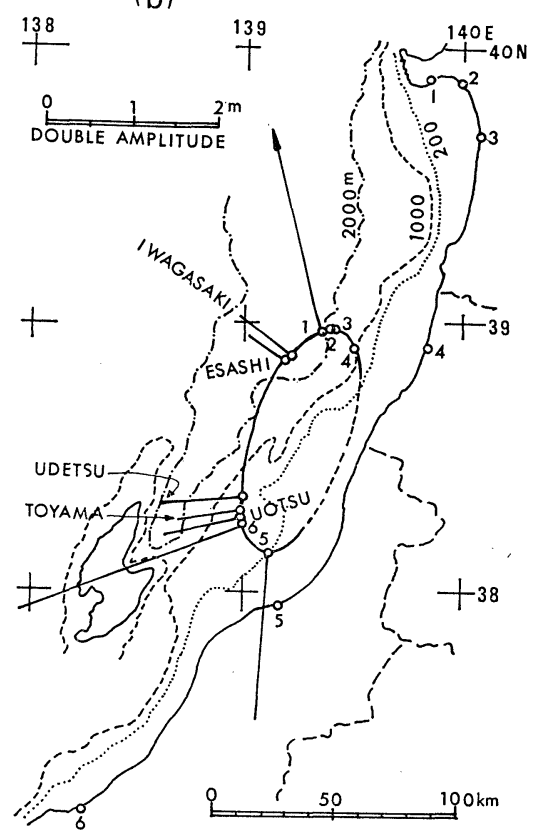

Fig. 3. The distribution of (a) the initial rise and (b) the maximum double amplitude of 1964 Niigata Tsunami at corresponded tide gage stations estimated from inverse travel time chart, and the earthquake mechanism. The stations are shown as number and name on the tsunami source.

3) 延びの方向は海域の活断層の走向と大体一致しているが, 1952 年十勝沖と 1953 年房総 沖は明かにほぼ直角となつている.

\section{§5. 津波の初動と最大波高, 震度}

\section{分布および地震のメカニズムとの関係}

津波の初動と最大波高（全振幅）は 津波の走時が 1 時間以内で, 波源の多 方向に数多く検潮記録が得られている ものを採用した．とくに，津波の走時 を 1 時間以内としたのは, 途中の伝ぱ んの影響をできるだけ少くするためで ある.このようにして採用された津波 は, Table 1 の No. 14 新潟地震津波, No. 15 日向灘地震津波, No. 16 十勝 沖地震津波, No. 19 宮城県沖地震津 波および No. 21 日本海中部地震津波 である.このほかの津波については，

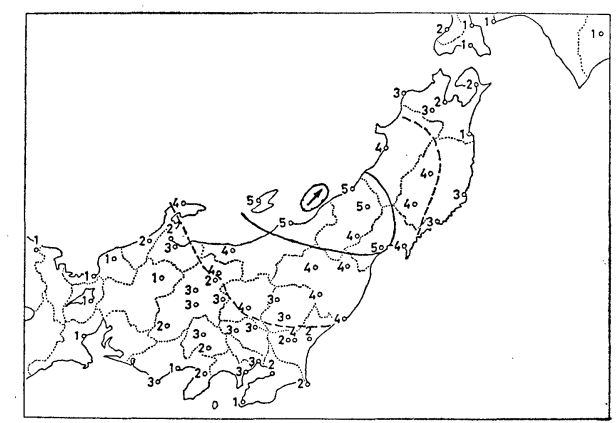

Fig. 4. The JMA Intensity Scale distribution of 1964 Niigata Earthquake and the tsunami source. Full lines show the boundary of the Intensities 4 and 5 , and dotted lines the one of the Intensities 3 and 4 . 


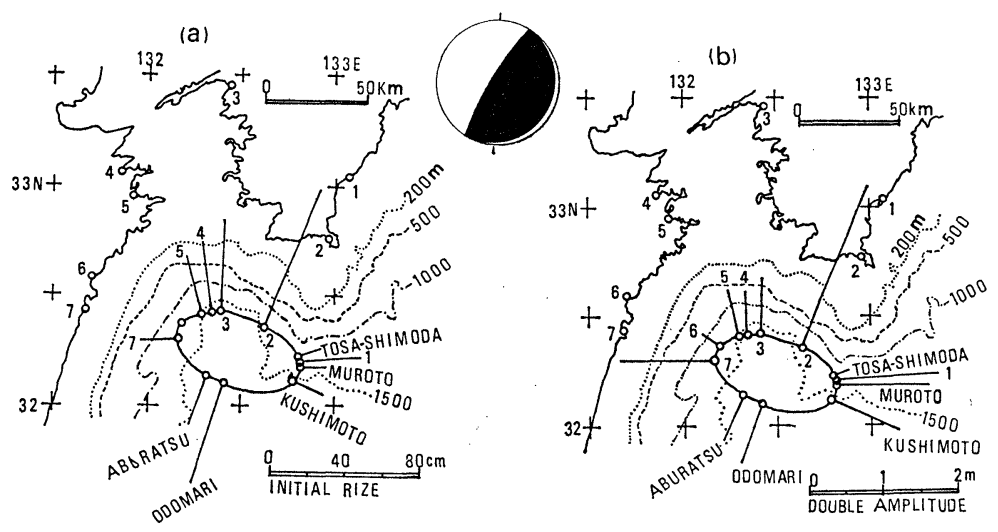

Fig. 5. The distribution of (a) the initial rise and (b) the maximum double amplitude of 1968 Hyuganada Tsunami at corresponded tide gage stations estimated from inverse travel time chart, and the earthquake mechanism.

満足すべきデータは得られなかつた.

Fig. 3 は 1964 年新潟地震津波である.この波源上の值は, 逆伝ぱん図から波源上の出発点 を推定し，ここから波として出発したものと仮定した．波源上の数字はそれぞれの沿岸の検潮 所の位置を示す同じ数字に対応するもので，また，地名は図に示す範囲外にある沿岸の検潮所 名である。（a）は初動振幅，(b) は最大波高（全振幅）で，スケールは左上に，また中央に地 震のメカニズムを図示した. Fig. 4 は震度分布で, 震度 5 と 4 の境界を実線, 震度 4 と 3 の境 界を点線で示した。

これらから次のことが分る.

1) 波源の延びの方向は断走の走向とほぼ一致している.

2) Fig. 3 (b) の観測点 2, 3 および 4 の記録は, 津波の初動を記録後, 検潮所が破損し, 測定不能となつたもので，かなり大きかつたと推定される．むた，波源の点線部分に相当する 山形県南部から新潟県北部にかけて津波の遡行高は大きかつた [気象庁 (1965)] が，海深数 $\mathrm{m}$

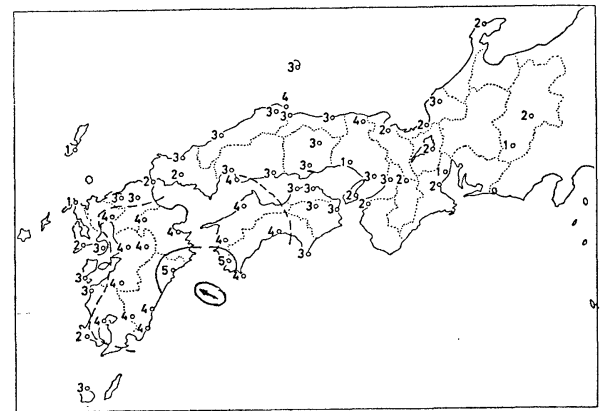

Fig. 6. The JMA Intensity Scale distribution of 1968 Hyuganada Earthquake and the tsunami source.
で観測している検潮記録（今回得られ なかつた）も比例して大きいとは限ら ず，むしろ小さい場合もあり得る[気 象庁 (1984)]. このように考觉ると， 津波の振幅は波源の長軸の方向，つま り断層の走向に大きくなつていると推 定出来そうである.

3）波源は海深 2,000 $\mathrm{m}$ より浅い ところに限られている.

Fig. 5 と Fig. 6 は 1968 年日向灘 地震津波のもので，それぞれ Fig. 3 と Fig. 4 に対応するものである.こ 


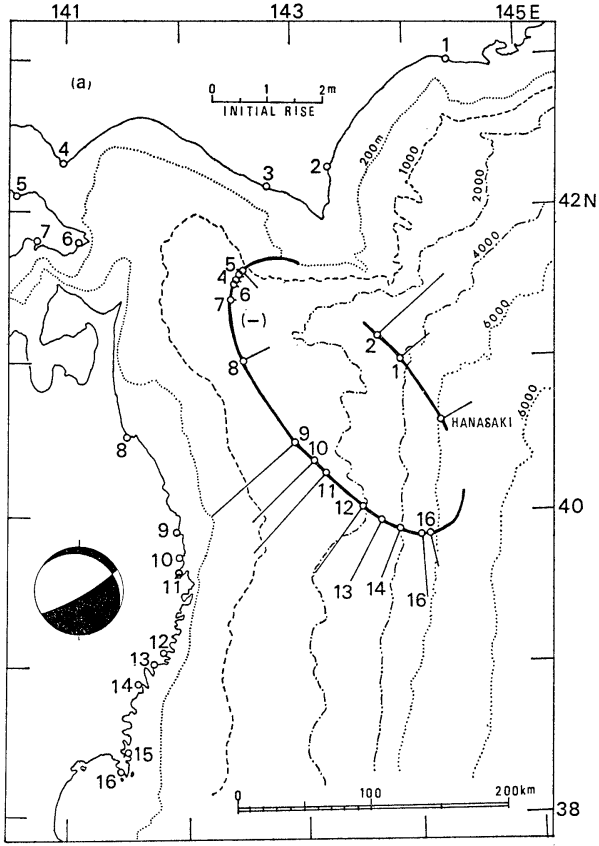

( a )

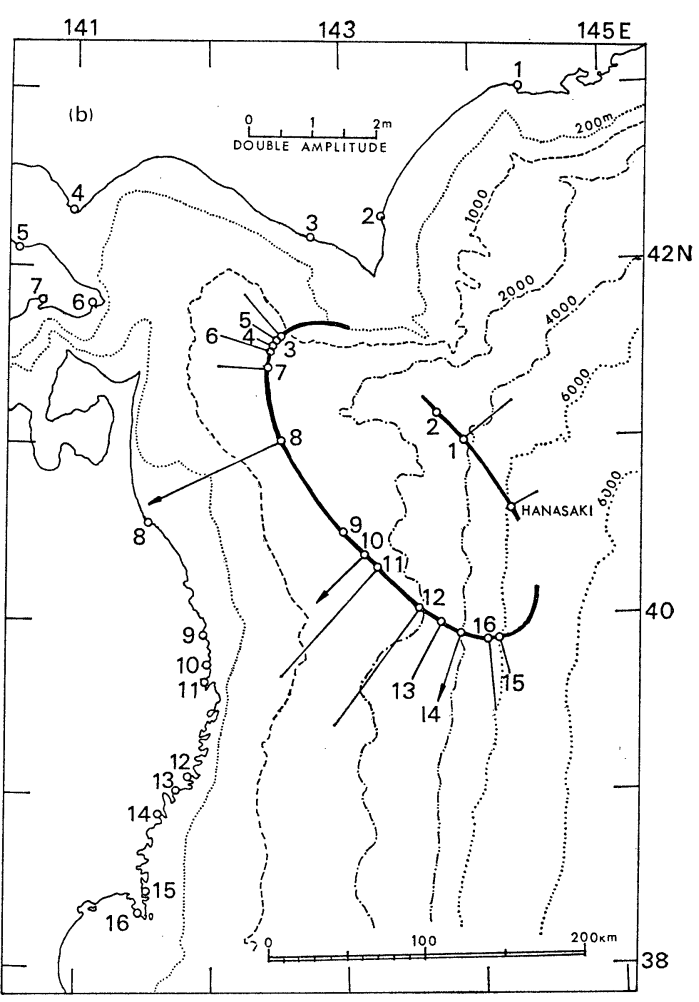

( b )

Fig. 7. The distribution of (a) the initial rise and (b) the maximum double amplitude of 1968 Tokachi-oki Tsunami at corresponded tide gage stations estimated from inverse travel chart, and the earthquake mechanism.

れらから，次のことが分る.

1) 波源の短軸の方向に大きな振幅が放出されている.これは前の新潟地震と異なるが，断 層の走向であることは同じである.

2) 波源全体は海深 1,500 m の線 とほぼ一致していることは興味深い. すなわち，波源形成は海底地形と密接 に関係しているように見える。

Fig. 7 (a)，(b) および Fig. 8 は 1968 年十勝沖地震津波のものである. これらから次のことが分る.

1) 波源の短軸の方向に津波の振幅 が大きくなつている.この振幅の大き い方向は断層の走向と一致しているよ うに見光る.この傾向は前の日向灘津 波と同じである。

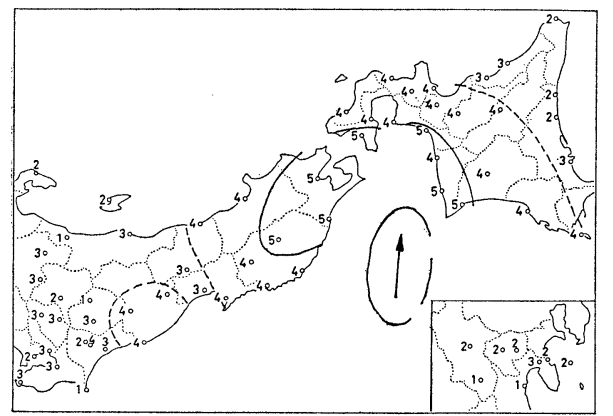

Fig. 8. The JMA Intensity Scale distribution of 1968 Tokachi-oki Earthquake and the tsunami source. 
(a)

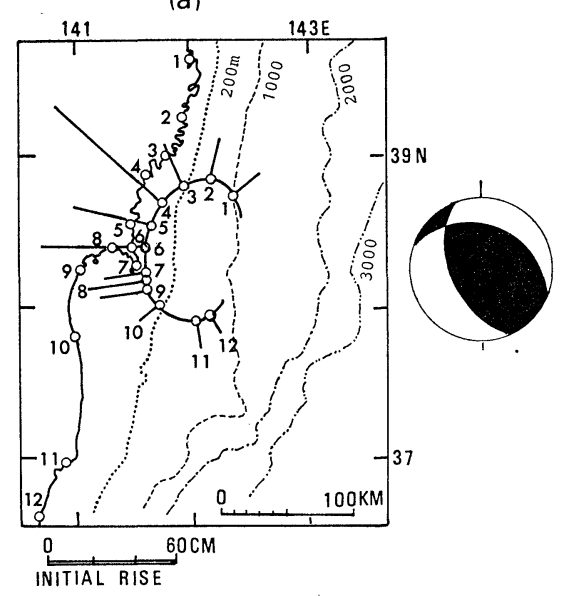

(b)

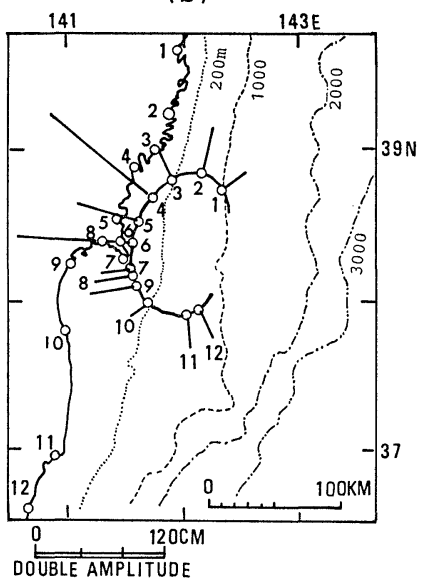

Fig. 9. The distribution double amplitude of 1978 Miyagiken-oki Tsunami at corresponded tide gage stations estimated from inverse travel time chart, and the earthquake mechanism.

2) 波源は千島海溝と日本海溝の接合海域を海深 1,000 m まで延びの形となつている。つ まり，海底地形や海溝の形状と密接に関係していることを示している. 長宗 (1969) によれば, 大きな破壊を発生した地点は震央よりかなり西の方向であつたといつていることから，津波の 波源形成は地震のメカニズムのほか, 海溝軸の折れ曲りに当つているこの海域のテクトニクス と密接に関係していると考えられる.

Fig. 9 と Fig. 10 は 1978 年宮城県沖地震津波のものである. これらから次のことが分る.

1) 津波は波源の短軸方向に振幅が大きい. 地震のメカニズムは上記 3 つのもと若干異な つているが，波源上の津波の振幅の大きい方向は，断層の走向と一致しているように見える.

2) 波源の伸びの方向が北向きを示し, 沖合の海域と反対であつたことは, 波源が $1,000 \mathrm{~m}$ より浅い陸地すれすれの海域に発生したこと，执よび地震のメカニズムによるものと思われる.

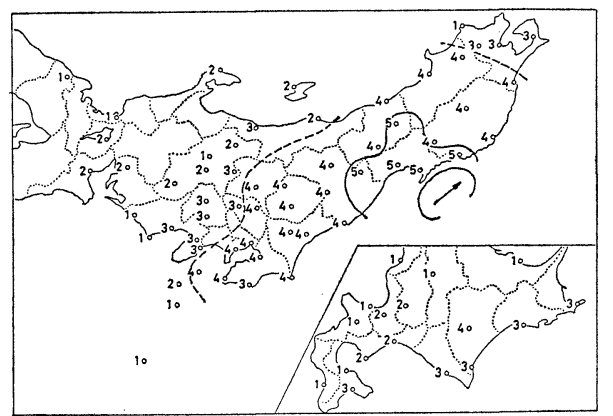

Fig. 10. The JMA Intensity Scale distribution of 1978 Miyagiken-oki Earthquake and tsunami source.
Fig. 11 (a), (b), Fig. 12 および Fig. 13 は 1983 年日本海中部地震津 波のものである.ここで, Fig. 13 は 太田ら (1984) の震度のアンケート調 查からの震度分布であるが，Fig. 12 と本質的に矛盾はない。これらから， 次のことが分る.

1）津波の振幅はかなり複雑で，初 動が長軸, 最大波高は短軸の方向に振 幅が大きくなつている。これは，図に 示した地震のメカニズムは pre-event のものであるが，このあと発生した 2 


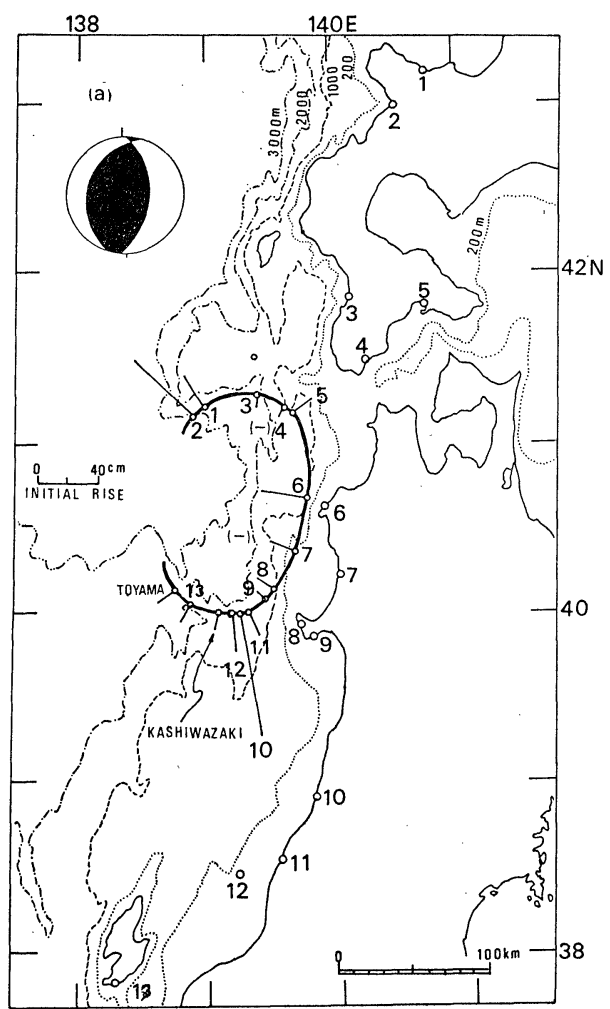

( a )

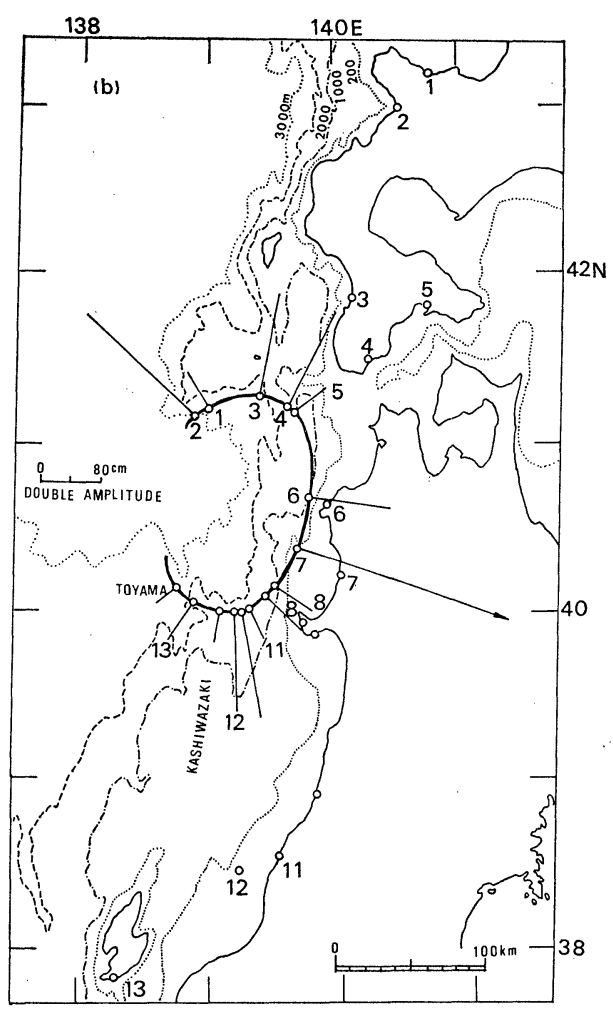

(b)

Fig. 11. The distribution of (a) the initial rise and (b) the maximum double amplitude of 1983 Nihonkai-chubu Tsunami at corresponded tide gage stations estimated from inverse travel time chart, and the earthquake mechanism.

つの event のメカニズムは若干異つており，波源形成として全体の断層の走向やすべりの方 向は複雑なものとなつたためであろう.

2) pre-event のメカニズムから見ると，断層の走向以南北方向で，波源もこの方向に延び となつていることは, 他のいくつかの津波と同じ傾向である.

\section{§6. ま と め}

データ数は限られているが，まとめてみると次のようになる.

1) 津波の波源の延びの方向は一見複雑に見えるが，発生海域の海底地形，プレートの形状， 地震のメカニズムなどと何らかの形で関係している.

2) 一般に同一海深とほぼ平行に津波の波源が延びている．ただし，十勝沖と日向灘に直角 に近いものがあるが，太平洋プレートとフイリピン海プレートの沈み込み境界の折れ曲りの位 置と関係がありそうである.

3）波源の延びの方向と地震断層のすべりの方向と一致するものが，十勝沖と房総沖拈よび 日向灘に存在する．また，断層の走向と一致しているところはその他の大部分である. 


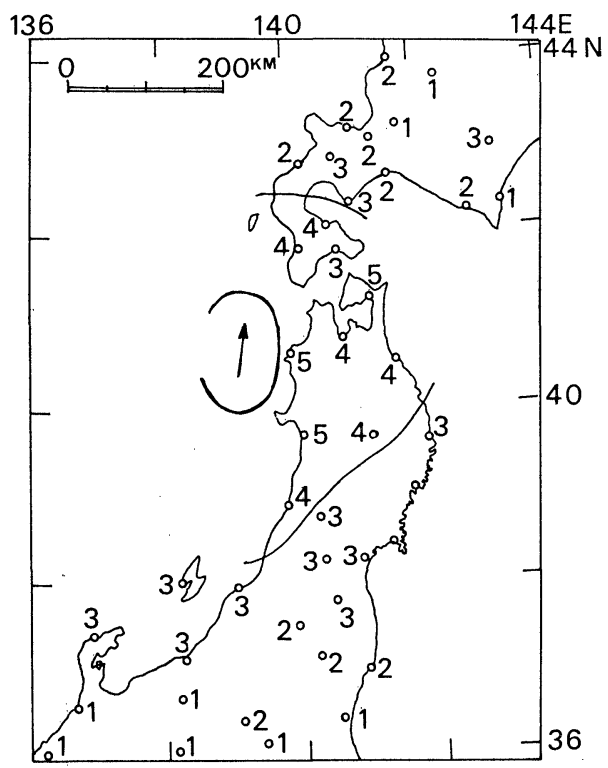

Fig. 12. The JMA Intensity Scale distribution of 1983 Nihonkai-chubu Earthquake and tsunami source.

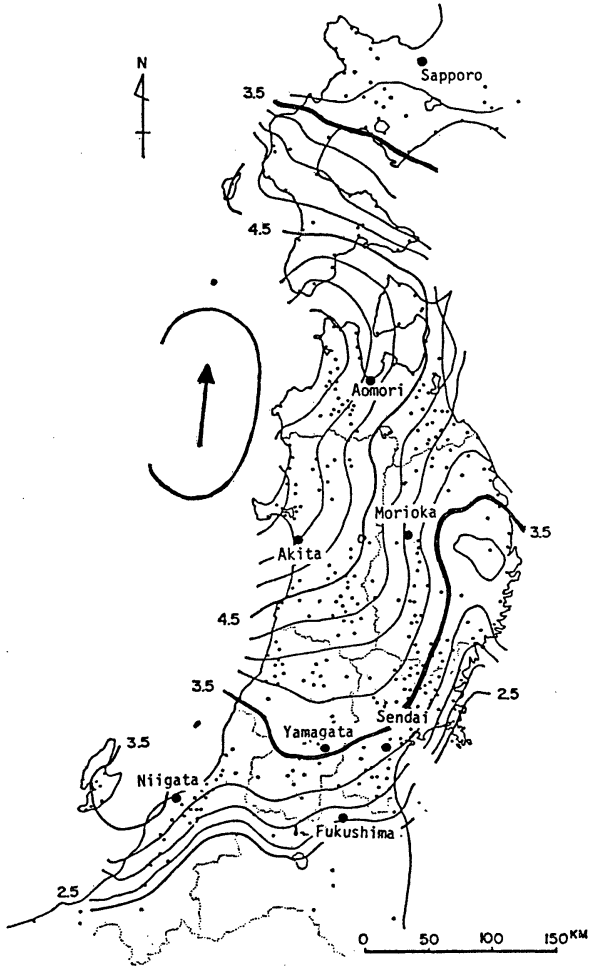

Fig. 13. The intensity scale distribution of 1983 Nihonkai-chubu Earthquake by OHTA et al. (1984) and tsunami source.

4) 波源の形に関係なく，津波の振幅の大きい方は断層の走向のようである. 波源の形に 関係するという研究もあるが [例えば，HATORI (1963)]，地震のメカニズムの方が影響が大き い. 震度の大きい方向も断層の走向に見られるものが多い.

5) 波源の延びの形は海溝軸の変わる海域，すなわち，十勝沖，房総沖および日向灘ではや や複雑となつている.

以上のように，津波発生は発生海域のテクトニクスなどと密接に関係していると思われるが， 各パラメータの精度の問題があるので, 定量的な議論については, 今後の研究にまちたい.

\section{謝辞}

気象庁地震津波監視課の徳永規一氏から，資料収集，作図などでお世話になつた。また，東 京管区気象台の永福順則氏にもご協力をいただいた。ここに厚く御礼申し上げる.

\section{文献}

HATORI, T., 1963, Directivity of Tsunamis, Bull. Earthq. Res. Inst., 41, 61-81.

羽鳥徳太郎, 1978, 1978 年宮城県沖津波と乞の近海の津波活動，地震研究所彙報， 53，1177-1187. 
羽鳥徳太郎，1981，歴史津波とその研究，(論文集)，356 pp.

羽鳥徳太郎, 1983a, 1982 年荻城県沖津波とその周辺海域の津波活動, 地震研究所䡬報, 58, 423-431. 羽鳥徳太郎, 1983b, 1983 年日本海中部地震津波の規模および波源域, 地震研究所彙報, 58, 723-734. 羽鳥徳太郎， 1984，1983 年日本海中部地震の余震に伴つた津波，地震研究所彙報， 59, 105-113.

ICHIKAWA, M., 1971, Renanlyses of Mechanism of Earthquakes which Occurred in and near Japan, and Statistical Studies on the Nodal Plane Solution Obtained, 1926-1968, Geophys. Mag., 35, 207-274.

ICHIKAWA, M., 1980, Some Problem in the Focal Mechanism in and near Japan, Geophys. Mag., 39, 1-22.

活断層研究会編, 1980 , 日本活断層一分布図之資料一東大出版会, $363 \mathrm{pp}$.

気象庁, 1965 , 昭和 39 年 6 月 16 日新潟地震調査報告, 気象庁技術報告, 第 43 号, $230 \mathrm{pp}$.

気像庁，1983，日本付近の地域・海域別の被害地震・地震津波の表挔よび震度分布図, $470 \mathrm{pp}$.

気象庁, 1984, 昭和 58 年 (1983 年) 日本海中部地震調査報告, 気象庁技術報告, 第 106 号, $252 \mathrm{pp}$. 長宗留男, 1969, 大地震生成の過程, 地震, 2, 22, 104-114.

中村一明, 1983, 日本海東縁新生海溝の可能性, 地震研究所壆報, 58, 711-722.

太田 裕, 鏡味洋史, 後藤典俊, 岡田成幸, 堀田 淳, 大橋ひとみ, 1984, 1983 年日本海中部地震に 伴う東北北海道地域市町村別震度調査, 1983 年日本海中部地震による炎害の総合的調査研究（自 然災害科学総合研究班), 176-179.

東大地震研究所, 1973, 図説日本の地震, 1872-1972 年, 東大地震研究所研究速報, 第 9 号, $136 \mathrm{pp}$. 渡辺偉夫，1964，新潟地震による津波の Generation Mechanism一津波の Source Function の問題 点一, 沿岸海洋研究ノート, 3, 31-37.

渡辺偉夫，1983，改訂日本拈よびその周辺の津波の表，地震，2，36，83-107.

渡辺偉夫，1984，改訂津波表から得られる日本拈よびその周辺に和ける津波発生の特徵，地震，2，37， 607-619. 